Synthesis, part of a Special Feature on A Social-Ecological Analysis of Diversified Farming Systems: Benefits, Costs, Obstacles, and Enabling Policy Frameworks

\title{
The Social Dimensions of Sustainability and Change in Diversified Farming Systems
}

\author{
$\underline{\text { Christopher M. Bacon }}^{1}, \underline{\text { Christy Getz }}^{2}$, Sibella Kraus $^{3}, \underline{\text { Maywa Montenegro }}^{2}$ and Kaelin Holland $^{1}$
}

\begin{abstract}
Agricultural systems are embedded in wider social-ecological processes that must be considered in any complete discussion of sustainable agriculture. Just as climatic profiles will influence the future viability of crops, institutions, i.e., governance agreements, rural household and community norms, local associations, markets, and agricultural ministries, to name but a few, create the conditions that foster sustainable food systems. Because discussions of agricultural sustainability often overlook the full range of social dimensions, we propose a dual focus on a broad set of criteria, i.e., human health, labor, democratic participation, resiliency, biological and cultural diversity, equity, and ethics, to assess social outcomes, and on institutions that could support diversified farming systems (DFS). A comparative analysis of case studies from California's Central Valley, Mesoamerican coffee agroforestry systems, and European Union agricultural parks finds that DFS practices are unevenly adopted within and among these systems and interdependent with institutional environments that specifically promote diversified farming practices. Influential institutions in these cases include state policies, farmers' cooperatives/associations, and organized civic efforts to influence agroenvironmental policy, share knowledge, and shape markets for more 'sustainable' products. The Californian and Mesoamerican cases considers organic and fair trade certifications, finding that although they promote several DFS practices and generate social benefits, they are inadequate as a single strategy to promote agricultural sustainability. The complex governance and multifunctional management of Europe's peri-urban agricultural parks show unexpected potential for promoting DFS. Unless DFS are anchored in supportive institutions and evaluated against an inclusive set of social and environmental criteria, short-term investments to advance diversified agriculture could miss a valuable opportunity to connect ecological benefits with social benefits in the medium and long terms.
\end{abstract}

Key Words: agricultural parks; Central Valley; Latin America; organic certification; sustainable agriculture

\section{INTRODUCTION}

Diversified farming systems (DFS) have been positioned as a more environmentally sustainable alternative to industrial monocultures (Kremen et al. 2012). DFS are "agricultural practices and landscapes that intentionally include functional biodiversity at multiple spatial and/or temporal scales in order to maintain ecosystem services that provide critical inputs to agriculture, such as soil fertility, pest and disease control, water use efficiency, and pollination" (Kremen et al. 2012). In this paper we explore criteria for assessing the social benefits associated with sustainable agriculture and the institutional contexts in which DFS might be realized. We interrogate these issues through three case studies that describe (1) the historical emergence of each farming system and (2) the social costs and benefits that have accrued as each system has evolved over time. Each case then considers a broader matrix of social institutional factors that contribute to (1) and (2) and that will influence the long-term potential to transition to DFS. Recent research suggests that DFS and similar farming systems can substantially reduce many of the high social and environmental costs of industrialized agriculture (Tegtmeier and Duffy 2004, Gliessman 2007, Hazell and Wood 2008, Pimentel et al. 2008).

We first briefly review the literature on the social dimensions of ecosystem stewardship and sustainable agriculture before introducing a framework for studying the social dimensions of DFS. We divide this analysis of social dimensions into two interconnected parts: first we propose a set of criteria for assessing the social side of sustainable agriculture (Table 1). We then situate these social metrics in the context of institutions, broadly defined as "the prescriptions that humans use to organize all forms of repetitive and structured interactions including those within families, neighborhoods, markets, firms, sports leagues, churches, private associations, and governments at all scales" (Ostrom 2005:3). Our proposed social sustainability criteria represent both outcomes and partial drivers of DFS, helping to create elements of a wider institutional context that can either encourage or impede realization of DFS principles and sustainability goals. We then use this conceptual framework to analyze three case studies. We selected cases based on our previous research and on the assumption that they were situated along what might be

\footnotetext{
${ }^{1}$ Department of Environmental Studies \& Sciences, Santa Clara University, ${ }^{2}$ Department of Environmental Science, Policy, and Management, University of California Berkeley, ${ }^{3}$ President Sustainable Agriculture Education (SAGE)
} 
Table 1. Proposed criteria for assessing the social dimensions of sustainability in diversified farming systems (DFS).

\begin{tabular}{|c|c|c|}
\hline Themes & Selected variables for analysis & Selected authors \\
\hline Human Health & $\begin{array}{l}\text { Food security, hunger, nutrition, wellness, morbidity and mortality from } \\
\text { pesticide exposures, food contamination, livestock to human diseases, } \\
\text { drinking water contamination, obesity. }\end{array}$ & $\begin{array}{l}\text { Fenske 2002, } \\
\text { Horrigan et al. 2002, } \\
\text { Lock et al. 2005, } \\
\text { Kerr et al. } 2007\end{array}$ \\
\hline Democracy & $\begin{array}{l}\text { Participation (voice and vote), decision making, rural associations/ } \\
\text { cooperatives, social capital and community cohesion, inequalities in social } \\
\text { power, representation, accountability mechanisms, food sovereignty, social } \\
\text { movements, governance and government policy (overlaps with equity and } \\
\text { justice) }\end{array}$ & $\begin{array}{l}\text { Flora 2003, } \\
\text { Fox and Gresham 2000, } \\
\text { Pretty and Ward 2001, } \\
\text { Allen } 2010\end{array}$ \\
\hline Work & $\begin{array}{l}\text { Paid and unpaid agricultural and food system labor } \\
\text { (within and beyond households). Employment, wages, changing labor } \\
\text { routines, injuries, migration/immigration, discrimination, collective } \\
\text { bargaining (overlaps with equity and justice, health) }\end{array}$ & $\begin{array}{l}\text { Carney and Watts } 1990, \\
\text { Kevane and Gray } 1999, \\
\text { Littig and Griessler 2005, } \\
\text { Getz et al. } 2008\end{array}$ \\
\hline $\begin{array}{l}\text { Quality of Life and Human Well- } \\
\text { being }\end{array}$ & $\begin{array}{l}\text { Income, economic poverty, education, employment, } \\
\text { housing conditions, security, life expectancy, as well as subjective } \\
\text { perceptions. (Links with health) }\end{array}$ & $\begin{array}{l}\text { Goldschmidt 1946, } \\
\text { MEA 2005, } \\
\text { Panelli and Tipa 2007, } \\
\text { UNDP } 2010\end{array}$ \\
\hline Equity, Justice, and Ethics & $\begin{array}{l}\text { Procedural and distributional dimensions of environmental and food justice. } \\
\text { Environmental and food access inequalities. Influence of geography, race, } \\
\text { class, gender and other markers of social identity upon the distributions of } \\
\text { environmental benefits and burdens in agri-food systems. Ethics of eating, } \\
\text { farming, food systems, and intergenerational ecosystem stewardship. }\end{array}$ & $\begin{array}{l}\text { Kloppenburg et al. 2000, } \\
\text { Dupuis and Goodman 2005, } \\
\text { Sneddon et al. 2006, } \\
\text { Gottlieb and Joshi 2010, } \\
\text { Alkon and Agyeman 2011 }\end{array}$ \\
\hline $\begin{array}{l}\text { Resiliency and } \\
\text { Vulnerability }\end{array}$ & $\begin{array}{l}\text { "The capacity of a system to absorb disturbance and reorganize while } \\
\text { undergoing change so as to still retain essentially the same function, } \\
\text { structure and feedbacks, and therefore identity, that is, the capacity to } \\
\text { change in order to maintain the same identity" (Walker et al. 2004). } \\
\text { Response to shocks (hurricanes, floods, droughts, market crashes, social } \\
\text { upheavals), coping mechanisms, livelihoods damage, and social learning and } \\
\text { local knowledge institutions }\end{array}$ & $\begin{array}{l}\text { Carpenter et al. 2001, } \\
\text { Turner et al. } 2003, \\
\text { Lin } 2007, \\
\text { Folke et al. 2010, } \\
\text { Wisner et al. } 2011\end{array}$ \\
\hline $\begin{array}{l}\text { Biological and } \\
\text { Cultural Diversity }\end{array}$ & $\begin{array}{l}\text { Cultural practices, languages spoken, indigenous } \\
\text { and hybrid ecological knowledge systems, diet, planned and associated } \\
\text { diversity in farms and forests, oral traditions (overlaps with resiliency and } \\
\text { vulnerability) }\end{array}$ & $\begin{array}{l}\text { Berkes et al. } 1995, \\
\text { Toledo et al. 2003, } \\
\text { Altieri 2004, } \\
\text { Johns and Sthapit 2004, } \\
\text { Maffi } 2005 \text {, } \\
\text { Chappell and LaValle } 2011\end{array}$ \\
\hline
\end{tabular}

thought of as a continuum, with some hewing closer to DFS principles, and others representing a departure. In our discussion, we compare the cases to assess how the institutional environment relates to the social metrics outcomes in different contexts. The issue of why some systems manage to adhere closely to DFS principles, while others diverge significantly is a pressing question that speaks to the reasons for this study: to make visible the myriad ways in which farming systems affect, and are affected by, human societies and the institutions they create. It is therefore vital, we suggest, to develop full-spectrum assessments of DFS that take into account both the institutional dynamics of sustainable agriculture and the many putative dimensions of societal well- being. Thus situated, DFS will be better able to connect ecological benefits and social benefits and pliable enough to adapt to human and environmental change.

\section{SUSTAINABILITY AND CHANGE IN AGRICULTURE AND FOOD SYSTEMS}

The social side of social-ecological agricultural systems

The ecological dimensions of DFS cannot be considered separately from its social dimensions. Agriculture itself is an integral nexus of society and ecology over time, a coevolution of culture and nature, humans and landscape (Zimmerer and Bassett 2003, Wells 2011). Industrial agriculture and the globalized food system have increasingly occluded this 
relationship, expanding the physical and cognitive distances among producers, consumers, and their supporting environments (Goodman and Watts 1997). An attempt to broach sustainable agriculture, therefore, demands attention to its social-ecological nature, and an understanding that agriculture produces landscapes that are at once social, cultural, and ecological (Cronon 1996, Wittman 2009). Our discussion of DFS begins on the foundation that social and ecological changes are mutually constitutive and work across spatial and temporal scales; accordingly, we understand that transitions toward DFS will be based on approaches that consider both sides of this relationship.

A central theme of many articles published in Ecology and Society remains the interdependencies that link ecosystems to socioeconomic-cultural issues across local, regional, national, continental, and global scales (Folke et al. 2007, Kok and Veldkamp 2011, Weber et al. 2012). In addition to developing frameworks useful for the interdisciplinary assessment of social-ecological systems, several recent articles have directly addressed the challenge of developing appropriate social indicators (Weber et al. 2012). The multidisciplinary problem of identifying the key social variables for studying complex social-environmental realities is often exacerbated by academic models that reward disciplinary-based research, the intellectual blind spots that prevail among many academics when it comes to critical issues and categories outside of their disciplines, and commonly shared perceptions about the feasibility of what can, or should, be measured (Norgaard and Baer 2005). For example, some social scientists prefer to focus on issues of health, demographic, and income data, whereas others are trained to assess qualitative measures concerning perceived quality of life, cultural vitality, and democratic decision making; a third group often studies issues of social power, political economic structures, and inequality. Atop these academic rigidities comes the inherently political, valueladen, and often-contested process of prioritizing the most important variables for analysis. Finally, there is the technical challenge of measuring these variables and tracking them over time and across spatial scales. Mitchell and Parkins (2011) navigated these many difficulties with an effective methodology: a workshop in which social scientists were invited to propose social indicators that could be incorporated into a cumulative effects model to display the anticipated impacts of regional land-use change and to aid in planning. The group identified no less than 30 different social metrics. Despite the complexity of this work, however, an increasing number of individual and international comparative studies are developing and applying interdisciplinary frameworks that prioritize variables and assess the social dimensions of agroecosystems.

The Millennium Ecosystem Assessment (MEA) is an influential example of this type of collaborative effort; integrating contributions from more than 1000 scientists, the
MEA generated a multidisciplinary framework for studying the effects of global environmental change on ecosystem services and human well-being (MEA 2005). The MEA framework defined human well-being as a multivariate state consisting of material for a good life, health, security, good social relations, freedom of choice and action (MEA 2005). Importantly, the MEA also went beyond the indicators of human well-being to consider ecosystem services that generate cultural and spiritual benefits. Subsequent studies identified the need to measure such qualitative and contextdependent variables with surrogate indicators and to more clearly quantify the trade-offs among different ecosystem services (Kareiva et al. 2007) and document the specific mechanisms connecting ecosystems stewardship with human well-being (Kareiva and Marvier 2007, Carpenter et al. 2009).

Another set of relevant social indicators emerged from several studies that focused less on ecosystem stewardship and more on agriculture as part of larger food systems. The International Assessment of Agricultural Knowledge, Science and Technology for Development (IAASTD 2009) united hundreds of experts to evaluate how agricultural knowledge, science, and technology impact:

- the reduction of hunger and poverty,

- the improvement of rural livelihoods and human health,

- equitable, and socially, environmentally, and economically sustainable development.

Among the subtitles in the assessment's executive summary were many useful categories for analyzing social dimensions of sustainable food systems: poverty and livelihoods, food security, human health and nutrition, equity, investments, trade and markets, traditional and local knowledge and community-based innovation, and women in agriculture (IAASTD 2009). Nearly a decade before the IAASTD report, Jack Kloppenburg, a long time agri-food systems scholar, set out to define the attributes of a sustainable food system with "competent, ordinary people" (Kloppenburg et al. 2000). He facilitated a dialogue with 125 members of the sustainable agriculture community during a conference in the United States in which the following terms were identified: ecologically sustainable, knowledgeable/communicative, proximate, economically sustaining, participatory, just/ ethical, sustainable regulated, sacred, healthful, diverse, culturally nourishing, seasonal/temporal, value oriented/ associated economics, and relational (Kloppenburg et al. 2000).

Assessing the social dimensions of sustainability in DFS We draw from the previous studies on the social dimensions of ecosystem stewardship and agricultural systems as well as common expectations associated with sustainable agriculture to propose a set of themes and variables for assessing the social 
dimensions of DFS. Notwithstanding previous research, the social dimensions of sustainable food and agricultural systems, especially with regards to issues of human rights, race, class, and gender, have often received less attention than the environmental and economic elements (Allen and Sachs 1991, Alkon and Agyeman 2011). Although the boundaries of a category as broad as 'social dimensions of sustainable agriculture' can be ambiguous, social scientific approaches commonly examine: (1) the interdependencies of social, economic, and ecological systems, (2) the social processes, patterns, and factors, that shape and maintain economic processes, (3) the social structures, values, and hierarchies often assigned to markers of identity such as race, class, and gender, and (4) the processes of decision making, alliance building, and governance, especially in relation to democracy and rights (Littig and Griessler 2005). Studying these processes enables researchers to relate context-specific variables to sustainability's normative goals of supporting biodiversity conservation, ecosystems services, and meeting the basic needs of all people in the present and future generations (Agyeman 2005).

We propose themes, variables for analysis, and examples of leading studies for assessing the social dimensions of sustainable agricultural and food systems (Table1). The list of categories is intentionally broad to represent the high aspirations of DFS and broad interpretations of sustainability (Kloppenburg et al. 2000, Sneddon et al. 2006). We reject the contradictory meaning of 'sustainable development,' which focuses on sustaining economic growth with little focus on basic human needs, justice, or ecological dimensions (Lélé 1991).

Though it would be very challenging for a single study to cover all themes, we argue that each is an important aspect of the social dimensions of DFS. All of our categories are contextdependent and shaped by their pre-existing environments, cultural values, livelihoods practices, and human aspirations. In practice, these categories constitute intersecting, transversal, and often interdependent themes.

The themes and variables in Table 1 also represent categories for assessing the social costs and benefits of DFS. Previous research addressing the benefits and drawbacks of industrial agriculture through the lens of sustainability identified similar categories (Tegtmeier and Duffy 2004, Hazell and Wood 2008, Pretty 2008). However, these studies were limited by what they could measure, quantify, and in most cases monetize (Pretty et al. 2000). One comprehensive study identified the following categories for assessing the externalities of the UK agricultural systems: damages to natural capital (water, air, soil, biodiversity, and landscape) and damages to human health (pesticide exposures and residues, nitrate contamination, microorganisms, and other disease agents; Pretty et al. 2000). Research in the U.S. calculated the substantial energy expenditures involved in both industrial agriculture and heavily meat dependent diets (Pimentel et al. 2008). Another global review considered industrial agriculture's impacts on hunger, health (issues ranging from pesticide exposures to agriculture- and food-related diseases), and the environment, with subcategories concerning deforestation, water depletion, soil degradation, biodiversity loss, and climate change (Hazell and Wood 2008). In contrast to studies that both identify and quantify externalities (Pimentel et al. 1992, Pretty et al. 2000, Tegtmeier and Duffy 2004), this study attempts to identify broad social metrics for agricultural sustainability.

\section{DFS are interdependent with changing institutional contexts}

Just as defining a common set of criteria is an important early step in assessing social sustainability of DFS, attention to the institutional context contributes to understanding the processes of emergence and change in agricultural systems. The preceding review shows that the social indicators of sustainable agriculture interweave social, economic, and ecological systems interacting at multiple temporal, spatial, and organizational scales. They illustrate that sustainable agriculture is not easily delimited at the plot, field, farm, or even landscape scale, but is embedded within much larger social-ecological systems.

Social institutions play a fundamental role in this dynamic process, and therefore, in creating the conditions that can enable or impede DFS. For even as DFS can contribute to a range of measurable social 'outcomes,' i.e., decreased exposure to pesticides, enhanced access to diverse foods, more autonomous farmers, these outcomes can in turn strengthen the capacity of farmers, laborers, consumers, and communities at-large to build and maintain the various institutions that comprise the agroecological landscape. In effect, sustainability-oriented institutions work through and beyond the conduits of a healthy food system to contribute to social welfare.

Thus, we turn now to three case studies to consider the processes of change through the lenses of evolving institutional contexts and our proposed criteria for assessing socially sustainable DFS. Although there are clearly a nearinfinite variety of institutional processes that might be relevant to food and farming, we give specific attention to: multistakeholder governance agreements, rural household and community norms, formal rules, and everyday practices of certified organic and fair trade agriculture, global financial investments, agricultural ministries, research and development programs, and commodities markets.

We selected case studies based on three criteria: (1) to represent a continuum ranging from agricultural systems that apparently adhere to many DFS principles to systems dominated by industrial monocultures (Kremen et al. 2012); (2) to cover a diversity of geographic contexts, i.e., tropical/ 
temperate, rural/peri-urban/urban, valley, mountains; and (3) based upon our existing knowledge. The first case involves smallholder shade coffee production systems in Mesoamerica's mountains. It includes a diverse livelihood and production system that conserves high levels of biological and cultural diversity adhering to many-but not all-DFS principles. The second case is of organic agriculture within the highly mechanized, chemical-intensive, market-oriented, capitalist production systems of California's Central Valley. It is clearly situated in a context that generally diverges from many of the ecological principles of DFS. Our third case, in the EU, falls somewhere in the middle of this continuum. This case documents how the expanding presence of multifunctional agricultural parks is influencing the landscapes and local food systems experienced by millions of Europeans. The agricultural production systems in the agri-parks case range from smaller scale diverse gardens and organic systems to larger scale industrial grain production; however, all agricultural parks are governed by public and private stakeholders who appear to value the landscape for its multifunctional benefits, including environmental conservation, recreation, food production, and cultural heritage preservation.

\section{MESOAMERICAN COFFEE AGROFORESTRY SYSTEMS}

\section{Traditional production systems, Green Revolution coffee monocultures, and the persistence of diverse shade farms}

Mexico and Central America's diverse coffee landscapes emerged over the course of more than 200 years, and today cover an estimated 1.5 million mountainous hectares, managed by some 500,000 farm families, and involving several million agricultural workers (Jha et al. 2011, Samper and Topik 2012). After the Colombian Exchange moved coffee seeds from the 'Old World' to the 'New World' in the late 18th century, elites in both Central America and Europe used their control over fledgling Latin American governments and their access to colonial resources, including slaves, to establish control of coffee-growing land, often displacing indigenous farmers (Topik 2009). However, indigenous systems persisted and evolved as millions of hillside farmers maintained their smallholdings and gradually incorporated coffee as an agroforestry crop that came to be grown much like their native cacao (Rice 1997). Coffee became part of broader land management systems that also include shade trees, 'milpas,' home gardens, community forests, and medicinal plants (Moguel and Toledo 1999, Méndez et al. 2010).

Coffee production continued to expand and change throughout the 20th century because of factors that included government policies, commodity market price booms and busts, and dynamics within households; fluctuations in local, regional, and global labor systems; and environmental conditions, e.g., crop diseases and pests (Samper and Topik 2012). The dramatic influence of government policy and direct state intervention was evident at several overlapping and interconnected levels, for example: redistributive agrarian land reforms in the 1980 s transferred $25 \%-40 \%$ of coffee lands from larger landholders to smallholders in parts of Nicaragua's coffee growing districts; in the 1970s and 1980s, Mexico's federal government directly purchased and exported most of the country's coffee, while governments from the U.S., Europe, and Latin America invested heavily in technological development and diffusion, including wet processing mills, chemical fertilizers, and new cultivars. In the 1990s, Mesoamerican markets and trade saw significant changes imposed from the international level, with IMF and World Bank policies that promoted deregulation and liberalization (Bacon et al. 2008). Although some polices prioritized smallholders, more frequently Mesoamerican governments, and the international development agencies that back them, have channeled agricultural support, such as forgivable loans, road construction, cheap fertilizers, and technical assistance, to the politically influential owners of large coffee plantations (Paige 1997). Even when governments sought to 'benefit' smallholders, they generally failed to see value in their cultural diversity and traditional ecological knowledge (Moguel and Toledo 1999), opting for a 'modernization' strategy focused on adopting new hybrid varieties, eliminating most shade trees, and increasing use of agrochemicals (Westphal 2008).

Latin American coffee production saw a dramatic shift in the 1960s and 1970s, when businesses, foundations, and northern governments began to promote the spread of Green Revolution technology packages in coffee (Perfecto et al. 1996). These technology packages included recommendations to eliminate shade trees, plant new varieties in higher density, and use agrochemicals (Perfecto et al. 1996, Rice 1997). The initial appeal to farmers included short-term crop yield increases, higher sales revenues, and the perception that fertilizers and increased sunlight could halt the spread of damaging pests, fungi, and diseases such as coffee leaf rust (Hemileia vastatrix; Staver et al. 2001).

\section{Social costs and benefits: assessing shade coffee households and agroecosystems}

Despite significant pressures on farmers to adopt Green Revolution packages, most farmers did not initially transition from their shade-grown polycultures to sun-grown coffee monocultures for several reasons (Jha et al. 2011). First, the shade coffee landscapes in El Salvador, Guatemala, Nicaragua, and parts of Mexico were sites of violent political conflict during much of this time period (Paige 1997). Second, these smallholders were a marginal population, generally without access to credit or technical assistance; thus, most families had created risk management strategies that combined subsistence production with diversified farms and livelihoods 
(Bacon et al. 2008). Finally, small-scale farmers and workers were more likely to note the decreased timber, fruit, and firewood yields following the disappearance of shade trees (Méndez et al. 2010). These factors notwithstanding, by the early 21 st century most farmers had experimented with at least some of the Green Revolution technologies; many planted one or more new coffee varieties, applied chemical fertilizers, to coffee, milpa, and other systems, when they could afford them, and adjusted their coffee management systems to the changing availability of both household and contracted labor (Guadarrama-Zugasti 2008). Researchers are only beginning to understand the cumulative effects of these changes.

A growing body of research has documented the consequences of Mesoamerica's changing coffee landscapes and livelihoods, assessing their implications for progress toward sustainable agriculture. Today, side-by-side comparisons of sun and shade agroforestry systems demonstrate substantially stronger ecosystem services in the latter along with higher levels of tree, bird, arthropod, and mammal species diversity (Philpott et al. 2008a). Crucially, these shade coffee farms are embedded in human community networks that serve to sustain cultural diversity and generate other social benefits. An estimated $60 \%-70 \%$ of Mexico's 280,000 coffee farmers are classified as indigenous and the percentages are even higher in Guatemala and other coffee regions (Jha et al. 2011). Smallholders in areas connected to indigenous governance systems and/or accountable smallholder cooperatives arguably enjoy more autonomy and democracy than do rural workers on larger coffee monoculture plantations (Nigh 1997). In addition, smallholders have less exposure to agrochemicals and cooler work environments because of the shade trees. A third social benefit is suggested by recent evidence that farmers with more trees in their systems were less vulnerable to hurricane damage (Philpott et al. 2008b). Such findings align with coffee value-chain studies showing that participation in fair trade networks partially buffered smallholders from the negative consequences of crashing commodity prices from 1999-2005. The many social benefits of coffee shade systems suggests that Mesoamerican smallholders are providing both ecological and social subsidies to stakeholders interested in biodiversity conservation, cultural diversity, and rural democracy (Bacon et al. 2008).

\section{The changing institutional context: new markets, persistent food insecurity, underpaid labor, and migration}

These social and environmental benefits should not be viewed as predetermined 'outcomes.' Rather, they are supported by specific combinations of rules, ethical positions, and practices within multiple social institutions that move these Mesoamerican coffee shade landscapes toward DFS. The persistence of traditional medicinal knowledge, for instance, requires training medicine-makers and establishing norms for the conservation of wild and cultivated medicinal plants. This process contributes to the preservation of the very high levels of biological diversity found within these systems (Toledo and Moguel 2012). Similarly, the creation and maintenance of accountable producer cooperatives can support higher revenues for farmers through access to specialty coffee markets; these same cooperatives can partner with wider producer networks and international development projects to enable social learning among farmers, improve their access to credit, and facilitate the transition to certified organic production. In some cases, people have created solidaritybased institutions connected to coffee farmers as part of a conscious effort to generate a more socially just and ecologically sustainable global trading system. More than 40 years ago, northern advocacy groups and enterprises collaborated with organized small-scale coffee farmers to create the fair trade system; their stated goals were to combat an unfair global free trade system that impoverished farmers and exploited environments (Bacon 2010).

By the early 1990s, a combination of specialty coffee roasters, scientists, and activist NGOs recognized the numerous social and ecological benefits of sustaining Mesoamerican coffee agroforestry systems and started to create alternative agri-food networks (Nigh 1997). These international alliances expanded upon the previous solidarity-trade oriented partnerships and promised better prices and more benefits for sustainable coffee, which many claimed also tasted better (Rice and Ward 1996, Jaffee 2007). These markets expanded rapidly in the past two decades, and with this change coffee sales by smallholder cooperatives increased. These cooperatives have allied with roasters, international development agencies, and certifiers to make their diverse landscapes more internationally visible. Coffee drinkers in developed countries have become increasingly aware of the social-ecological issues in production; in response, more than 30,000 Mesoamerican farmers have converted to certified organic production and hundreds of thousands of consumers have accessed fair trade markets (Bacon et al. 2008).

Although these new 'sustainable' markets have provided higher per-pound prices and have contributed to improved ecological management and social development, i.e., scholarships to send the children of coffee farmers to school through to university, research suggests they are also associated with additional costs, i.e., the extra work associated with improving coffee quality and certification audit trials, and that certifications alone are insufficient to guarantee sustainable livelihoods or DFS. In fact, an expanding body of research and rural development projects seek to understand and eliminate seasonal hunger and food insecurity in these coffee-growing regions (Caswell et al. 2012).

Initially, the spread of certified organic and fair trade coffee farming occurred primarily within the pre-existing indigenous shade agroforestry systems. Several key aspects of the organic 
and fair trade auditing systems, such as group-based inspections, were designed to fit relatively well with endogenous forms of organizing and farming (Nigh 1997), though other facets created tensions through their influence upon labor routines, gender relations, and community leadership responsibilities (Mutersbaugh 1998). However, in the past decade much has changed. Instead of building from local community and agroecological knowledge institutions that support DFS, rapidly expanding market opportunities and NGO development projects have encouraged thousands of farmers to quickly convert from low-input chemical systems to certified organic production. Although this trend has generated benefits, such as the elimination of chemical fertilizers and herbicides, in many cases the 'organic training' was superficial and led to promises of price premiums that did not always materialize. In place of agroecological proposals to redesign the farming system for integrated pest management, the push of certification is often to complete detailed paperwork associated with the audit trail and to increase yields by thinning shade trees. In some cases, technical-assistance agronomists encourage farmers to simply substitute agrochemicals with expensive bio-based organic fertilizers that must still be purchased off-farm each year. Rules and incentives have also changed in parts of the global fair trade system. The dominant agency that licenses the use of the fair trade label in the U.S. recently broke away from the global fair trade system and launched an initiative to certify large coffee plantations. This break represents a dramatic change for a certification process that has more than two decades of history working exclusively with smallholder cooperatives (Bacon 2010). Changes such as these, to institutions that once strongly supported DFS and social sustainability, underscore why questions of democracy, justice, and equity continue to surface within the global coffee value chain.

Meanwhile, human migration rates from coffee growing regions remain high, sometimes sending former Mesoamerican smallholders to become farmworkers in California's Central Valley (Fox and Bada 2008). Because of a combination of drivers that include forces well beyond certifications and coffee markets, these communities continue to suffer deteriorating social cohesion and possibly lower levels of agrobiodiversity, as the people who once applied the knowledge and skills to the many plants in the milpa system travel north (Robson and Berkes 2011).

\section{AN ORGANIC ALTERNATIVE IN CALIFORNIA'S CENTRAL VALLEY?}

\section{The spread of industrial capitalist agriculture}

Agriculture is the most economically important activity in the 18 counties that comprise California's Central Valley, generating $\$ 18$ billion in annual sales, occupying more than $7,000,000$ acres of irrigated land, and accounting for $20 \%-40 \%$ of employment in the Central Valley. The claim that California agriculture is "capitalist through and through" (Walker 2004) is reflected most notably in the Central Valley. Although exceptions can be found, Central Valley agriculture has been mostly industrial, commercial, and capitalist on small and large farms alike for at least 100 years. By the 1920s, the Central Valley was the largest stretch of irrigated farmland in the world. The combination of government subsidies, infrastructure investments, and technological advances in the biology, pedagogy, hydrology, chemistry, and mechanics of agriculture shaped this landscape and defined the social costs and benefits throughout the 20th century (Walker 2004).

As has been documented widely in the literature (Guthman 2004, Howard 2009), California's organic sector, long heralded as promoting an alternative to the industrialized agriculture found in the Central Valley, has grown at exponential rates since the 1980s. But to what extent does organic agriculture in the Valley counter or replicate this industrial model? Debates about the "conventionalization" of the organic agriculture sector as a whole have swirled since this thesis was put forward in the late 1990s (Buck et al. 1997). We explore the extent to which organic agriculture in its current form represents an alternative to the specific trajectory of agriculture in the Central Valley. To accomplish this analysis, we look at the social costs and benefits of organic agriculture in this region with a particular focus on democracy, labor, and health.

\section{Social costs and benefits: the question of scale in assessing socioeconomic inequities, labor, and health}

The political economic structure of agriculture in the Central Valley, like that in most regions of the U.S., is increasingly polarized. Historically one of the world's most productive agricultural regions, the Central Valley now exhibits trends toward the disappearance of midsize farms and proliferation of both large farms and very small, micro, hobby, residential, and retirement farms (Lyson et al. 2008). The organic sector as a whole has come to replicate this polarization. In 2005, for example, $7 \%$ of organic farming operations in California accounted for $75 \%$ of sales, while $75 \%$ of operations accounted for just $7 \%$ of sales (Getz et al. 2008). This polarization is even more severe in the Central Valley, and, as we will show below, the conventionalization thesis holds more strongly in the Central Valley than in other parts of the state, minimizing the organic sector's potential to either pose a viable alternative to industrialized agriculture or provide a path toward more diversified farming systems. As a result, the organic landscape in the Central Valley increasingly disenfranchises small organic farmers as large organic, and mixed organic/conventional, growers hold greater shares of economic and political power, which minimizes the influence of smallholders, consumer groups, and environmental justice advocates in the struggle for change within these agri-food systems and communities. 
We used data on labor conditions on California organic farms from 300 grower surveys conducted in 2006 by researchers at UC Berkeley and the California Institute for Rural Studies to compare the organic sector in the Central Valley to other regions (see also Strochlic et al. 2009). Included in the sample were growers who reported hiring at least one worker, either directly or through a farm labor contractor, as well as farms that were either all-organic or mixed conventional/organic. Based on Guthman's (2004) demonstration that there is significant variation across California's growing regions with respect to cropping patterns, labor intensity, and orientation toward markets, we suspected the landscape of organic agriculture would also differ by region. In our sample we had 43 growers (14.5\%) from the Central Valley North and 37 growers $(12.5 \%)$ from the Central Valley South. Central Valley North is comprised of the counties of Calaveras, Madera, Mariposa, Merced, Mono, San Joaquin, Sacramento, Stanislaus, Tuolumne, and Yolo; Central Valley South is comprised of the counties of Fresno, Inyo, Kern, Kings and Tulare. The Central Valley organic sector, our data suggests, more closely resembles agribusiness than other regions of the state: organic farms in the valley as a whole (and particularly in the South Central Valley) are more likely than farms in other regions to be mixed organic/conventional than all-organic. Although organic growers in the valley have farmed longer than growers in other regions, they have farmed organically for fewer years than their counterparts in other regions. Anecdotal evidence suggests that late adopters of organic, who transitioned some of their land into organic from conventional production, are more likely to have entered the organic sector in response to market growth and the potential for garnering price premiums, as opposed to having a commitment to the principles of organic production.

Transition to organics for many of these larger mixed growers was likely facilitated by the enactment of the 1990 National Organic Food Production Act and ultimately the implementation of the National Organic Program, which has been criticized for favoring large, corporate agriculture over smaller, higher bar organic operations (DeLind 2000). Ironically, these larger growers are effectively entrenching their power in and through the transition to organic. What we get in the valley, as a result, is a system that is less democratic, and less pluralistic. For example, we see more economic and acreage polarization in the valley, and in the south valley in particular, than in other regions of the state. One is more likely to find organic monocropping in the south valley than in the north valley, because in the north valley we documented a significantly larger proportion of organic farms with mixed cropping systems. In the Central Valley, as in the state as a whole, we found that small farms are more likely to be diversified than large farms, although $82 \%$ of all organic farms surveyed reported having five or fewer organic crops in production, with $48 \%$ reporting only one crop. We also found that small farms are significantly more likely to be all-organic than larger farms, measured both in terms of acreage and annual sales. Figure 1 demonstrates the overall predominance of farms with high sales in the valley as compared to other regions in the state, particularly in the south valley, which includes the two largest agricultural counties in the country, Fresno and Tulare.

Fig. 1. Farm size by sales class and region in California.

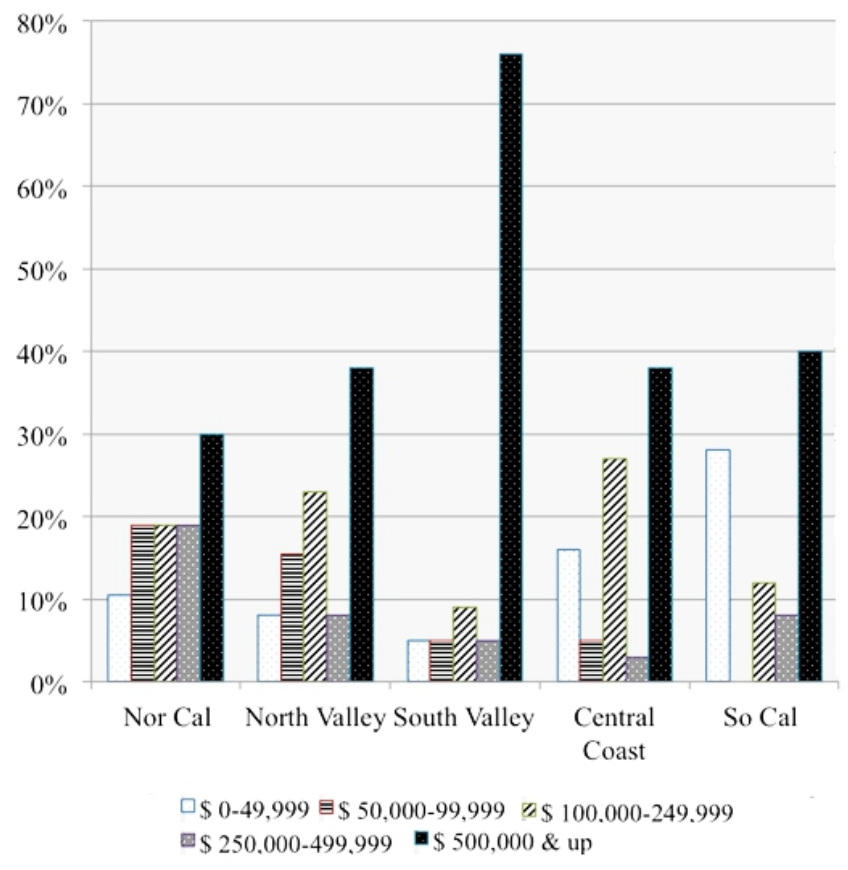

The question of scale has also emerged in discussions of the labor question in California agriculture. Contravening agrarian rhetoric that romanticizes organic farms as relying on family labor only (Getz et al. 2008), many in the organic agriculture "movement" take huge strides to avoid the labor question altogether, with the overall sense that "it's not our issue." (Shreck et al. 2006). Nonetheless, the vast majority of organic farms in the Central Valley, regardless of the type or size, are part of the larger structure of agriculture that rests on the back of a demographic consisting primarily of Hispanic farmworkers from Mexico and Central America. Historically, various waves of immigrants have worked on California's farms, including the Chinese, Japanese, Filipino, Punjabis, Mexicans and Central Americans. The processes by which these immigrant groups have been "churned through" the agricultural labor regime have been enabled and facilitated by racist citizenship, immigration, and regulatory policies, which Richard Walker characterizes as "vast, repetitive cycle of recruitment, employment, exploitation and expulsion" (Walker 2004:66). Though California has passed several measures supporting farmworker protections to fill in for their glaring omission from the 1935 National Labor Relations Act, 
key differences remain between protections for California's farmworkers and those for laborers in most other sectors; one conspicuous difference is the lower standard for overtime pay. Attempts to close gaps in labor protections have been vociferously opposed by the organic industry (Getz et al. 2008).

Organic growers in the valley differ from those in other regions on a variety of fronts. For example, valley growers pay lower than average wages within the overall survey sample and are more likely to use farm labor contractors. Specifically, the mean entry-wage for all-organic farms was about $\$ 1.50 /$ hour lower in the valley than in other regions of California. On the other hand, valley growers are more likely to provide traditional benefits, such as health insurance and paid vacation, and to have established management systems in place than are growers in other regions.

Corroborating findings from previous studies (Guthman 2004, Shreck et al. 2006), our survey results indicated a correlation between organic production and increased year-round employment in all regions of the state. Also, small organic growers reported significantly higher retention rates for both permanent and seasonal workers. Given that labor often substitutes for synthetic inputs on many organic farms, it was not surprising that organic farms in the valley, as in the state as a whole, had more workers per acre than mixed organic/ conventional operations.

Like labor circumstances, the health of farmers, farmworkers, and local populations as a result of organic farming practices presents a mixed picture. In the Central Valley, pesticide drift has been documented as a key environmental justice issue (Harrison 2008), and consumers' preference for organic food has been explicitly linked to perceptions that it is "safer" than its conventional counterpart because its lacks pesticide residues (DeLind and Howard 2008). However, studies have shown that musculoskeletal injuries, not pesticide exposure, account for the vast majority of acute farmworker injuries (see Villarejo and Baron 1999). These injuries arise primarily from labor activities such as stooping, climbing, lifting, and reaching (Getz et al. 2008). Discussions with farmworkers indicate that the stoop labor required for hand weeding, the vast majority of which occurs on organic farms, is the primary contributor to injury on the farm. (Getz et al. 2008) In fact, the organic industry vehemently opposed, and ultimately led the defeat of, a bill to ban hand weeding in California agriculture (Getz et al. 2008).

\section{Social institutional context: continuity or change?}

As we can see from our discussion on the effects of the organic sector on health and labor, contradictory evidence puts into question the potential importance of organic agriculture as an alternative to industrialized agriculture in the Central Valley. Evidence suggests that most farmers in the Central Valley were late adopters of organic agriculture, implying that they were led more by economic motivations than by a commitment to the ideological and agroecological foundations of the organic movement. Evidence also suggests that organic agriculture in the valley, particularly in the counties of Fresno, Tulare, Inyo, and Kern, is more likely to replicate the practices of conventional agriculture, including monocropping, than in other parts of the state. Given that the USDA's National Organic Program is particularly friendly to these large, industrialized organic growers, it is unlikely that the current "conventionalization" of organics in the valley will lead to the diversified farming that is often associated with organic agriculture. Without targeted changes to the institutions that govern California agriculture, even smaller, ecologically diverse organic farms will not be able to mitigate the socioeconomic polarization, health perils, and labor injustices in which Central Valley agriculture as a whole has become increasingly embedded. Indeed, the increasing political and economic power of the large-scale mixed conventional/ organic growers in the Central Valley underscores that the social and environmental justice potential of DFS will be increasingly harder to achieve in this agriculturally important region.

\section{PERI-URBAN AGRICULTURE IN EUROPEAN UNION METRO REGIONS}

\section{Emergence}

Peri-urban agriculture has been recently defined "as a multiactor, multi-function, multi-scale agriculture based on the provision of food and fiber supplies along with environmental and social services...with the aim to satisfy societal demands locally" (Lardon et al. 2010:11). The importance of agriculture and nature as an integrated landscape, the emphasis on diverse production including traditional products, and the prioritization of local sales are all points of connection to DFS. Most of these connections between DFS and peri-urban agriculture are manifested at the landscape or territorial scale; there are also connections at the field scale through the promotion of environmentally friendly farming methods (Maranges 2005). Emphasis on social, environmental, and economic multifunctionality is a fundamental element in discussions about peri-urban agriculture in the European Union, as the examples below demonstrate.

Agricultural parks, also called agrarian parks, are a type of land use designation that has been in place in Europe for several decades, although the designations usually overlay types of land use that have been in place for centuries. These parks are characterized by peri-urban location and urban development pressures, historical agriculture activities often interspersed with villages, natural lands within and around agricultural landscapes, traditional products, multifunctional agriculture with operators of various scales and levels of commercialization, and a considerable level of public commitment to enact and implement dynamic preservation 
policies. All are governed through multijurisdictional systems involving actors with vested interest in peri-urban agriculture: residents, policy makers, and the agricultural community.

\section{Changing institutional context}

Within the European Union's Common Agricultural Policy (CAP), most of the initiatives and projects for promoting Ag Parks are part of agroenvironment measures within the CAP plan for Rural Development. The EU has supported these agroenvironment schemes since it introduced them through the 1992 CAP reforms. But as the CAP has shifted emphasis from subsidizing food production to promoting the farmer as custodian of the landscape, agroenvironment measures have gained new prominence; for the period 2007-2013, these measures encourage farmers to provide environmental services that go beyond following good agricultural practice and basic legal standards. In addition, special measures related to 'conservation and upgrading rural heritage' have helped to fund agricultural parks projects including ecological restoration and landscape-scale ecological infrastructure management. Financing for these and other rural development programs in EU Member States comes mostly from the European Agricultural Fund for Rural Development (EAFRD).

One of the most established EU agricultural parks is the Parco Agricolo Sud (Southern Agricultural Park) in Milan in the fertile Po River plain. First conceived in the 1960s as an extensive green belt wrapping around the southern half of the city as well as a critical element for preserving the area's agricultural heritage, the park was established by regional law in 1990. It has three interconnected institutional objectives: conservation of biodiversity, development of sustainable agriculture, and the integration of sustainable forestry practices. The park encompasses around 47,000 hectares of permanently protected land of which almost $80 \%$ is in active agriculture. There are over 1000 farms in the park, with one concentration of larger farms in a rice-growing area and another in a pasture-and-field crop rotation area. In 2007, less than $10 \%$ were certified organic or in the process of converting to organic, although a large number of farms used some DFS practices (Brembilla 2005).

Included in this agricultural landscape mosaic are 61 small towns and villages, significant cultural and historical landmarks such as abbeys and canals, and natural features including wetlands, springs, hedgerows, and woods. Various research projects, such as a study of birds in hedgerows, have demonstrated the correlation between sustainable agricultural practices and environmental outcomes at the landscape scale. Other projects, such as promotion of agrotourism and "supplier of environmental quality' labeling, have directly promoted multifunctional agriculture practices as a means for achieving economic, environmental, and social objectives. According to Bruna Brembilla, until recently the president of the park, protection and enhancement of the parks' ecological and cultural networks is integral to productive agricultural activity.

Ownership of the land is mostly private $(\sim 80 \%)$, while town councils own $20 \%$ of the land. In terms of administrative structure, the park is managed by an ad hoc entity referring to the county government (Provincia di Milano). Public funding accounts for most financing (60\% is provided by the Provincia di Milano, $19 \%$ by Regione Lombardia, and $1 \%$ by the municipalities), and the remaining $20 \%$ comes from private contributions and user fees.

The 2938 hectare Baix Llobregat Agricultural Park, located on the western edge of Barcelona in the low-lying valley and delta of the River Llobregat, is another example of a designated, multifunctional peri-urban EU agriculture zone that emphasizes social benefits. The park is operated by an Agricultural Park Consortium, with representation from multiple local and regional governments. The consortium has adopted a park management plan with clear social and ecological requisites: "to facilitate the continuity of agriculture by promoting specific programs which enable the preservation of values (productive, resource-based, ecological and cultural) and to develop the functions (economic, environmental and social) of the agricultural area in the framework of sustainable agriculture integrated into the area and in harmony with the natural environment and its surroundings" (Maranges 2005:1).

The park's management plan addresses the social dimensions of the park by engaging multiple types of stakeholders, both individual participants and jurisdictions. The stakeholders emphasize increasing farmers' incomes through providing production assistance for environmentally friendly farming methods; payments for ecosystems services, for example, seasonal flooding of fields for habitat benefit; cooperative infrastructure, such as facilities for supplies and services, called an Agropolis; a park-wide security service to prevent crop robberies and illegal dumping; and marketing initiatives around farm product identification, such as quality and origin designations. Consumers receive value from the park through access to its branded fresh products and through public education initiatives, including one called the Agricultural Ecosystem, a teaching program for middle-school children.

Recently, the engagement of the park's multiple stakeholders has been put to the test by a single powerful stakeholder: a casino consortium seeking to establish a major international casino on part of the park's land. The Parco Agricolo Sud Milano faces a similar challenge in the form of the development of part of its land for the 2015 World Expo. Although both of these challenges have been held at bay, at least to date, they illustrate the vulnerability of commitments to urban-edge agricultural land uses in the face of potentially higher returns and new jobs; even short term and/or low paying 
jobs can pose a grave risk to agricultural parks during eras of high unemployment.

Challenges notwithstanding, there are many other formalized efforts to sustain peri-urban agriculture in the EU. Many are not organized as agricultural parks per se, but are also characterized by a multijurisdictional, multiactor, and multifunctional approach. For example, the Ile de France region, where agriculture predominates (53\% of land use), has 11.5 million inhabitants (18\% of the French population) in 1281 municipalities ranging from the Paris center to small rural communities (Guiomar 2010). The region now aims to improve local agricultural coherence and resilience through numerous governmental and market-based strategies: increasing the percentage of organic farms (from $1 \%$ to $6 \%$ ), encouraging a local food movement, and stemming the increase in farm consolidation. This effort entails understanding the interconnectedness of, and as possible harmonizing, policies from many levels, including local and regional authorities, national policies, and EU Common Agricultural Policies.

\section{Social costs and benefits: quality of life, biological and cultural diversity}

Rooted in the institutional context of local to EU-wide policies and incentives, the EU multifunctional peri-urban agriculture zones, as exemplified above, demonstrate multiple social benefits. Such benefits accrue to farmers, nearby urban residents, and to the region as a whole. The primary benefits to farmers are in the social criteria areas of 'work' and 'quality of rural life,' resulting from diversification of income through agricultural tourism and through payments for ecosystem services. Local residents gain human health benefits through access to fresh, traditional foods, access to natural and agricultural landscapes close to urban centers, and opportunities for direct relationships with producers. Regional social benefits are in the areas of democracy, resiliency, quality of rural life, and cultural and biodiversity conservation. Democratic participation and overall rural livelihoods have improved through the active engagement of producers, rural residents, nearby urban residents, and visitors, in management, stewardship, and recreational activities. Cooperation among multiple stakeholders at multiple levels of government, meanwhile, has resulted in increased employment opportunities. Resiliency and biological and cultural diversity have benefited from manifold factors: preservation of agricultural culture, historical landscapes, and wildlife; preservation of traditional varieties, breeds, and processing techniques; and protection of agricultural-natural areas close to cities as a means of mitigating both the causes and the negative impacts of climate change.

Information about social costs is not readily available. It can be surmised that they include: lost opportunity costs as a result of disincentives for highly industrialized, vertically integrated farming systems; the resources required for multistakeholder governance of multifunctional agriculture, as well as the payments for crop subsidies, cultural preservation practices, and/or ecosystem services. Clearly, more study is needed to assess social benefits and costs and clearly connect them to the evolving roles, incentives, and norms established by these public-private governance institutions.

\section{DISCUSSION: THE INSTITUTIONAL CHALLENGES OF CREATING SOCIALLY SUSTAINABLE DFS IN THREE AGRICULTURAL SYSTEMS}

We began this study on early evidence that alternative farming practices can curb many of the social problems associated with industrialized agriculture and generate social benefits among smallholders (Altieri 2002, Gliessman 2007, Hazell and Wood 2008, Pimentel et al. 2008). Our initial goals were to understand where and how DFS could be part of larger interconnected relationships that generate their welldocumented ecological benefits and promote an expansive set of goals associated with social sustainability. Based on our previous research and familiarity with the cases, we anticipated that the Mesoamerican coffee systems would show the highest levels of social sustainability and the presence of many key DFS practices, and that organic agriculture in the Central Valley would show relatively small changes in both areas. We thought that the European Ag-Parks would fall somewhere in the middle of this three-case spectrum. Case study narratives and analyses summarized in Table 2 reveal that our initial assumptions were only partially accurate. The Ag Parks showed a surprisingly wide range of social benefits, fewer apparent costs, and significant long-term potential for advancing both DFS and social sustainability. On the other hand, coffee systems were characterized by their well-known high levels of biological and cultural diversity and important struggles for justice, equity, and democracy, but also revealed a lack of DFS practices in subsistence food production, and mixed assessments for several social metrics. For example, the persistence of food insecurity and human illness negatively influenced health scores in Mesoamerica, while selected institutional trends, such as migration, threaten long-term labor stability. The empirical evidence from California's Southern Central Valley corroborates previous research, which suggested that the rapid scale-up of organics into industrialized conventional agri-food systems could result in substantial changes to the meaning and practice of organic farming and relatively unchanged agricultural landscapes (Goodman 2000). In short, the study underscores how the agroecological principles and ethos of sustainable agriculture that once defined organics can, in the absence of supportive institutions, give way to conventional supply chain management and contract farming (Goodman 2000).

The number and type of DFS practices in each case are highly uneven and reflect farming systems grounded in very different agroclimatic and institutional environments, and shaped by 
Table 2. Cross-case comparison of social sustainability and institutional change.

\begin{tabular}{|c|c|c|c|}
\hline Criteria & Mesoamerican coffee systems & Organics in CA Central Valley & $\begin{array}{l}\text { European Peri-Urban } \\
\text { Ag Parks }\end{array}$ \\
\hline $\begin{array}{l}\text { Social sustainability } \\
\text { assessment }\end{array}$ & $\begin{array}{l}\text { Democracy }++/- \\
\text { Human health }++/ \text {-Equity and Justice }+ \\
\text { Diversity }++/- \\
\text { Resiliency }+\end{array}$ & $\begin{array}{l}\text { Democracy - } \\
\text { Human health }++/- \\
\text { Equity and justice }-/+\end{array}$ & $\begin{array}{l}\text { Democracy }++ \\
\text { Human health }+ \\
\text { Diversity }+ \\
\text { Resiliency }+\end{array}$ \\
\hline $\begin{array}{l}\text { Level of DFS adoption } \\
\text { Common DFS and } \\
\text { conventional farming } \\
\text { practices }\end{array}$ & $\begin{array}{l}\text { Medium to high } \\
\text { DFS: Agroforestry, multicropping, } \\
\text { organic composting, live fences, } \\
\text { landscape level forest conservation. } \\
\text { Conventional low input: corn and beans } \\
\text { production often uses some fertilizers, } \\
\text { herbicides, and pesticides. }\end{array}$ & $\begin{array}{l}\text { Relatively low } \\
\text { DFS: organic production, nutrient } \\
\text { management, crop rotations, elimination } \\
\text { of most agrochemicals } \\
\text { Conventional high input: Many mixed } \\
\text { organic/conventional producers in } \\
\text { Central Valley are employing } \\
\text { monocropping across both sectors and } \\
\text { using chemically intensive practices on } \\
\text { their conventional land. }\end{array}$ & $\begin{array}{l}\text { Medium, but highly heterogeneous } \\
\text { DFS: Heritage crops, landscape forest } \\
\text { fragments, and other natural habitats. } \\
\text { Conventional: high input industrial } \\
\text { monocultures common in some places. }\end{array}$ \\
\hline Key governance institutions & $\begin{array}{l}\text { Contested multistakeholder groups set } \\
\text { and change certification standards }\end{array}$ & $\begin{array}{l}\text { National government ministries and } \\
\text { contested multistakeholder negotiation }\end{array}$ & $\begin{array}{l}\text { Government led multistakeholder } \\
\text { negotiations. }\end{array}$ \\
\hline $\begin{array}{l}\text { Institutions pushing the } \\
\text { system away from DFS } \\
\text { practices and sustainability }\end{array}$ & $\begin{array}{l}\text { Out migration } \\
\text { Superficial farmer training } \\
\text { Green Revolution } \\
\text { Revisions to Fair Trade standards that } \\
\text { the decrease smallholder benefits } \\
\text { Limited national government investment } \\
\text { in rural health, agricultural worker rights }\end{array}$ & $\begin{array}{l}\text { Access to subsidized water } \\
\text { National and state wide labor- } \\
\text { immigration policy } \\
\text { Organic certification standards that } \\
\text { allow input substitution }\end{array}$ & $\begin{array}{l}\text { Highly dependent on government } \\
\text { funding. } \\
\text { Recent historical legacies of } \\
\text { conventional monocultures. }\end{array}$ \\
\hline $\begin{array}{l}\text { Institutions moving the } \\
\text { systems toward DFS and } \\
\text { sustainability }\end{array}$ & $\begin{array}{l}\text { Local plant knowledge } \\
\text { Cooperatives } \\
\text { Farmer learning networks } \\
\text { Alternative trade networks } \\
\text { Civic advocacy }\end{array}$ & $\begin{array}{l}\text { Few identified in California's Central } \\
\text { Valley. Organic certification requires } \\
\text { elimination of pesticide and chemical } \\
\text { fertilizer use but does not require } \\
\text { improved soil fertility management or } \\
\text { more crop rotations }\end{array}$ & $\begin{array}{l}\text { Civic participation in governance. } \\
\text { Multifunctional agriculture policy. } \\
\text { Clearly defined land tenure and } \\
\text { geographic bounties. } \\
\text { Large local market for diverse } \\
\text { "heritage" foods and landscapes. }\end{array}$ \\
\hline
\end{tabular}

The case of ++ indicates a very strong link with DFS and social sustainability, + a weaker link, and +/- indicates the presence of institutions that are contested with some forces advancing these criteria and others weakening the presence.

DFS $=$ diversified farming systems.

Ag Parks = agricultural, or agrarian, parks

disparate historical processes of political economic change. As noted in Table 2, the initial adoption of certified organic in California's Central Valley occurred in the context of a system consisting primarily of irrigated monoculture grown in a highly mechanized environment upon flat fertile soil. The adoption of organic farming did not change these practices, although it stopped farmers from applying pesticides, herbicides, and chemical fertilizers on certified parcels. Diversified farming practices are more common in Mesoamerica's tropical shade coffee systems, in which smallscale farmers are dependent upon rainfall as they combine a mix of perennial and annual crops, grown upon steep mountain slopes, for both household subsistence and sale to global market. Europe's peri-urban agricultural parks were established upon a pre-existing heterogeneous landscape consisting of irrigated monocrops, market farms, natural areas, and recreational green spaces. Most production is mechanized, and the terrain ranges from flat river valleys to rolling hills.

Taking into account this context, we found that the degree to which each farming system in our case studies approximated industrialized/conventional agriculture correlated with measured social benefit outcomes. In Table 2, we summarize these social metric assessments. The positive and negative scores in these cases are generalizations and should be seen as a starting point for follow-up research and more nuanced analysis; they are based upon the case study narratives and expert opinion of the authors. In some instances, we can make informed observations linking social benefits to the extent and type of diversified farming practices. For example, the fact that resiliency and biological and cultural diversity are high in both Mesoamerican coffee shade systems and European Ag Parks, the two cases with medium-to-high DFS practices, 
suggests the possibility of a positive correlation that could be explored through future field research.

Democracy, a broad category in which we include participation, decision making, community cohesion, political representation, and accountability mechanisms, among others, also showed a strong correspondence to DFS practices. Here again, the cases of Mesoamerican coffee and EU Ag Parks scored highly on measures of democracy, while also evincing the higher levels of DFS practices. This finding resonates with previous research out of Latin America indicating that the process of creating a grower cooperative and establishing the trust necessary for collectively exporting coffee, managing credit programs, and paying farmers, can create 'rural social capital.' These associative ties are strengthened even further through the struggle for securing sustainable farmer livelihoods and the pursuit of larger social and political goals (Bacon et al. 2008). In some cases, we also found contradictory trends within the same broad category, and the same system. For example, Mesoamerican smallholder systems generally advance rural democracy through smallholder cooperatives and their multistakeholder governance structure for setting fair trade standards. However, the recent unilateral decisions by a certification agency and the increasing influence of large corporate firms indicate a countervailing trend.

These dynamics point to the difficulty, indeed the impossibility, of prizing apart 'social criteria' for DFS from their broader institutional contexts. From fair trade certification standards in Nicaragua to immigration policy in the U.S., from global development banks to local farmers markets, institutions both within and beyond the food system fundamentally configure the potential for alternative agriculture to thrive. Thus, we now turn to consider how institutions variously create or impede possibilities for DFS, drawing from our case study systems for larger insights on social sustainability goals.

\section{Historic legacies and path dependent development}

Institutions at the national government level were critical to catalyzing the emergence of each system and to shaping their subsequent trajectories. Frequently, government investments and policy changes followed a combination of changing market conditions and citizen demands for a different system; government actors often formed broader institutional arrangements with farmers, nonprofit organizations, and firms. For example, in the Central Valley, the U.S. government financed water infrastructure projects that, contrary to their stated intent, furthered land consolidation. More recently, national state and municipal governments were key participants in negotiating multilayer agreements to establish agricultural parks adjacent to many European cities. The U.S. federal government also worked closely with the growers in the Central Valley to create a supply of relatively low-cost labor through immigration policies; their selective enforcement of these laws has marginalized farmworkers and complicates efforts to improve labor conditions. Certainly government actions alone do not explain the emergence of these systems: export sales to global markets also contributed greatly to the birth of both the Latin American coffee production system and industrial agriculture in the Central Valley (Raynolds 2004).

Market institutions are a strong determinant of the day-to-day continuity of each system, and they are often the short-term cause of changes. The influence of price and demand, especially, can be seen in the way that coffee and many commodity crops expand and contract with cycles of boom and bust (Samper and Topik 2012). The many adaptive measures that Mesoamerican small-scale shade coffee farmers employ as they combine subsistence crops with cash crop exports in their struggle for survival illustrates how local livelihoods and global markets codetermine the endurance of a given system, even as that system evolves through migration, climate change, and other forces (Eaken and Lemos 2006). The California case also demonstrates how increased market demand for an alternative product such as organic food can prompt many large-scale, commercial operations to shift to new production systems. Yet the shift toward organic production did not substantially change the extant industrial practices or transform structural inequalities, as demanded by the original pioneers of sustainable organic agriculture and advocates of social development.

\section{Institutions that impede or enable DFS and social sustainability}

What, then, can encourage the expansion or survival of DFS and promote the social dimensions of sustainability? In this study, we offer neither magic bullets nor quantitative multivariate analysis about what percent of an outcome can be attributed to a specific social variable. However, one social metric strikes us a fundamentally important: the influence of dynamic and accountable farmer and citizen organizations. These findings are consistent with several comparative international studies that document the key role of local associations and social capital in promoting sustainable agriculture, with benefits ranging from higher yields to wider adoption of DFS practices, and achieving a broad set of social goals (Pretty and Ward 2001).

Mesoamerica's smallholder cooperatives have made substantial contributions to securing farmers' land tenure, protecting shade coffee landscapes, and advancing the DFS practices that support these systems (Bacon et al. 2008). These organizations are also the starting point for creating partnerships with sustainable agriculture enterprises and civil society institutions in Europe and North America. Such transcontinental partnerships have spawned several sustainability certification programs for tropical commodities, enabling thousands of farmers to convert to certified organic 
production, and supporting social development projects ranging from disaster relief to gender equity to adult literacy. Intricately-knit local institutions, such as accountable cooperatives and indigenous land tenure systems, together with cross-scalar networks of knowledge sharing, development projects, and fair traders are thus playing a crucial role in sustaining farmer livelihoods in Mesoamerica's shade coffee and milpa landscapes. Certainly the ecologies of this region's pre-existing forests, and the indigenous agroforestry practices that seek to mimic these ecologies, represent a social-ecological system resonant with agroecological and DFS principles (Gliessman and Rosemayer 2009). However, without comprehensive strategies to share local knowledge among farming communities, sustain effective ties to transnational institutions, and assure food security in the context of a changing climate, the long-term sustainability of these shade coffee systems is increasingly in jeopardy. Some proponents of fair trade have proposed shifting support away from organized producers, allowing export firms to buy directly from unorganized individual farmers. Many scholars and longtime participants in the fair trade movement, however, argue that this move risks undermining a core democratic institution of fair trade.

In the case of European Ag Parks, municipal, national, and other government authorities established multistakeholder negotiation platforms with citizen groups, farmers and others interested parties. This broad network comprising political, civic, and farmer interests collaborated to define the multifunctional values of the parks, and to develop incentives and management plans in accordance with these values. These multistakeholder governance forms are not a typical rural producer association; yet, they also represent a form of social capital. It is still unclear the degree to which these agricultural parks have changed or will change existing production systems beyond enabling the persistence of agriculture in places threatened by urban expansion. We suggest that the value they place on a mosaic of natural and agricultural landscapes, interspersed with cultural/historical features, as well as the spaces for rest and recreation they provide to the citizens of dense urban areas, may enable the transition of these landscapes from their current focus on production toward a civic-oriented DFS.

Finally, the case of organic agriculture in California's Central Valley is notable for the near-absence of influential smallscale farmer organizations, sustainable agriculture advocates, and consumer associations. Larger scale growers, landowners, and conventional food processors and exporters have created multiple avenues for influencing government policy, organic standards, and the flow of benefits from government subsidies, public-private research, and agricultural development partnerships. Meanwhile, grassroots organizations that often promote DFS practices, farmworker rights, and environmental justice have received relatively little funding and political support (Walker 2004). This analysis considers the relative political and economic power of different organized producer groups that seek to maintain organic standards in the interests of industrial agriculture, not in the interest of social justice or environmental sustainability. Indeed, this power serves to reproduce organic agriculture in the model of the dominant agri-food system, while marginalizing the dynamic efforts of immigrant farmers and farmworkers (Minkoff et al. 2011). The Central Valley case suggests a pressing need to analyze the ethics, goals, and actions within institutions such as farmer and consumer organizations. It also demonstrates that organic production and DFS will likely change labor routines and thus could intersect with established production cultures to create new burdens on farmers and workers, suggesting the need for continued study and adjustments to labor-related institutions (Mutersbaugh 2004, Getz et al. 2008). Advocates of DFS, including those from within the organic movement itself, will want to tailor incentives, norms, and rules to prioritize ecological and social sustainability as conscious goals.

\section{Organizations and social movements}

Ultimately, the social changes that could enable DFS to scaleup and scale out will be fashioned by the aspirations and actions of people (Kloppenburg et al. 2000). They will be shaped by the farmers, citizens, advocates, companies, scientists, and consumers who collectively push for decent labor conditions in California, create markets that support sustainable coffee farmers, and demand livable cities across Europe. They will be forged by social organizations that recognize the many different influences and potential sources of authority in agricultural systems. Although the transition to DFS may begin with grassroots initiatives, these efforts must eventually engage the dominant institutions that structure agrifood systems in each context. This paradox, of being both within and beyond the system one seeks to change, could easily result in alternative schemes that quickly conform to the food systems they were designed to transform (Taylor 2005, Bacon 2010). One way to navigate this difficulty is through sustained political will, critical and reflexive research, and constant willingness to rework strategies. Social movements could generate a significant portion of the energy, ideas, and inspiration for this challenging work.

The rising food movements, especially the currents concerned with food justice, agroecology, cooperatives, and food sovereignty, are promising forces that could redirect agri-food systems and invigorate institutions in which the rules and norms have drifted away from sustainable DFS models (Sevilla-Guzmán and Martinez-Alier 2006, Gottlieb and Joshi 2010, Holt-Giménez and Shattuck 2011). Food sovereignty, broadly defined as "the right of nations and peoples to control their own food systems" (Wittman et al. 2010:2), has particular salience for DFS, in that it integrates many of the social dimensions criteria proposed here, including democracy, 
cultural and biological diversity, resiliency, equity, ethics, and justice. The social movements that have taken up food sovereignty explicitly emphasize exerting political agency over the food system, over markets, production modes, food cultures, and environments. In positioning food sovereignty as a radical alternative to the dominant neoliberal model for agriculture and trade, its supporters are working to promote agroecological production strategies and socially embedded trade relationships that ensure the alternative nature of this proposition.

Of course, the theoretical definitions and practical applications of food sovereignty continue to evolve, and food sovereignty is but one current among many collectively constituting the 'social food movements.' The future trajectories of these food movements are passionately debated; many movements are themselves split as to whether efforts should focus on changing the current food system or on creating alternative food systems that could serve as models for further innovation. Critical attention to these avenues of change is vital, because social food movements and the initiatives they support are proliferating in ways that will fundamentally influence the social dimensions of sustainability, and the potential to strengthen DFS.

\section{CONCLUSION}

In this paper, we illustrate that DFS are interdependent with a set of institutional environments that specifically promote diversified farming practices and that enhance the social benefits of sustainable agriculture. We proposed a dual-lens framework that combines the analysis of a broad set of social assessment criteria with the consideration of wider institutional environments. Applying this framework to our three case studies, we studied processes that represent potentially viable strategies for enhancing social sustainability and expanding the use of DFS in three very different settings. Each case is influenced by the particularities of history, culture, geography, and political economy that make universal guidelines difficult to propose at this point in the research agenda. However, at least one strategic principal is clear: unless DFS are linked to supportive institutional environments and evaluated against an inclusive set of social and environmental criteria, short-term investments to advance diversified agriculture will miss an opportunity to connect ecological benefits with social benefits in the medium and long terms. In fact, these interconnections must emerge to enable the persistence of DFS.

Against the dominant paradigm of industrial agriculture, which externalizes social and ecological costs, undermining the very systems that support food production, the spread of DFS can begin to reprioritize local knowledge, ecology, and social development. Supported by people and the institutions they create, DFS can contribute to broader efforts that seek to improve the quality of rural life, assure workers' rights, enable rural democracy, conserve biodiversity, and sustain cultural traditions.

Responses to this article can be read online at: http://www.ecologyandsociety.org/issues/responses. $\mathrm{php} / 5226$

\section{Acknowledgments:}

We are very grateful for encouragement, edits, and insightful comments from Alastair Iles as we developed significant revisions to this manuscript following his considered review. We would like to thank two peer reviewers for significant comments and suggestions that contributed to our revisions. We also appreciate Sandy Brown who was so helpful in analyzing data for the Central Valley case study. Finally, we would like to thank the members of the Center for Diversified Farming Systems for their enthusiasm for the broad scope of this paper and the avalanche of useful feedback they shared after we presented our initial plans for revision in May 2012.

\section{LITERATURE CITED}

Agyeman, J. 2005. Sustainable communities and the challenge of environmental justice. New York University Press, New York, New York, USA.

Alkon, A. H., and J. Agyeman. 2011. Cultivating food justice: race, class, and sustainability. MIT Press, Cambridge, Massachusetts, USA.

Allen, P. 2010. Realizing justice in local food systems. Cambridge Journal of Regions, Economy and Society 3 (2):295-308. http://dx.doi.org/10.1093/cjres/rsq015

Allen, P. L., and C. E. Sachs. 1991. The social side of sustainability: class, gender and race. Science as Culture 2 (4):569-590. http://dx.doi.org/10.1080/09505439109526328

Altieri, M. A. 2002. Agroecology: the science of natural resource management for poor farmers in marginal environments. Agriculture, Ecosystems \& Environment 93 (1-3): 1-24. http://dx.doi.org/10.1016/S0167-8809(02)00085-3

Altieri, M. A. 2004. Linking ecologists and traditional farmers in the search for sustainable agriculture. Frontiers in Ecology and the Environment 2(1):35-42. http://dx.doi.org/10.2307/3868293

Bacon, C. M. 2010. Who decides what is fair in fair trade? The agri-environmental governance of standards, access, and price. Journal of Peasant Studies 37(1):111-147. http://dx.doi. org/10.1080/03066150903498796 
Bacon, C. M., V. E. Méndez, S. R. Gliessman, D. Goodman, and J. A. Fox. 2008. Confronting the coffee crisis: fair trade, sustainable livelihoods and ecosystems in Mexico and Central America. MIT Press, Cambridge, Massachusetts, USA.

Berkes, F., C. Folke, and M. Gadgil. 1995. Traditional ecological knowledge, biodiversity, resilience, and sustainability. Pages 281-299 in C. A. Perrings, K.-G. Mäler, C. Folke, C. S. Holling, and B.-O. Jansson, editors. Biodiversity conservation: problems and policies. Kluwer Academic, Dordrecht, The Netherlands.

Brembilla, B. 2005. The Parco Agricolo Sud Milano: between agriculture and environmental conservation. Fedenatur, Barcelona, Spain. [online] URL: http://www.fedenatur.org/ docs/docs/155.pdf

Buck, D., C. Getz, and J. Guthman. 1997. From farm to table: the organic vegetable commodity chain of northern California. Sociologia Ruralis 37:3-20. http://dx.doi.org/10.1111/1467-9523.00033

Carney, J., and M. Watts. 1990. Manufacturing dissent: work, gender and the politics of meaning in a peasant society. Africa 60(02):207-241. http://dx.doi.org/10.2307/1160333

Carpenter, S. R., H. A. Mooney, J. Agard, D. Capistrano, R. S. DeFries, S. Díaz, T. Dietz, A. K. Duraiappah, A. OtengYeboah, H. M. Pereira, C. Perringsk, W. V. Reidl, J. Sarukhanm, R. J. Scholesn, and A. Whyte. 2009. Science for managing ecosystem services: beyond the Millennium Ecosystem Assessment. Proceedings of the National Academy of Sciences 106:1305-1312. http://dx.doi.org/10.1073/ pnas.0808772106

Carpenter, S., B. Walker, J. M. Anderies, and N. Abel. 2001. From metaphor to measurement: resilience of what to what? Ecosystems 4:765-781. http://dx.doi.org/10.1007/s10021-001-0045-9

Caswell, M., V. E. Méndez, and C. M. Bacon. 2012. Food security and smallholder coffee production: current issues and future directions. Agroecology and Rural Livelihoods Group, University of Vermont, Burlington, Vermont, USA.

Chappell, M. J., and L. A. LaValle. 2011. Food security and biodiversity: can we have both? An agroecological analysis. Agriculture and Human Values 28(1):3-26. http://www. springerlink.com/content/k082605n4r641231/

Cronon, W. 1996. The trouble with wilderness; or, getting back to the wrong nature. Environmental History 1(1):7-28. http://dx.doi.org/10.2307/3985059

DeLind, L. B. 2000. Transforming organic agriculture into industrial organic products: reconsidering national organic standards. Human Organization 59:198-208.

DeLind, L. B., and P. H. Howard. 2008. Safe at any scale? Food scares, food regulation, and scaled alternatives.
Agriculture and Human Values 25(3):301-317. http://dx.doi. org/10.1007/s10460-007-9112-y

DuPuis, E. M., and D. Goodman. 2005. Should we go "home" to eat?: toward a reflexive politics of localism. Journal of Rural Studies 21:359-371. http://dx.doi.org/10.1016/j.jrurstud.2005.05.011

Eakin, H., and M. C. Lemos. 2006. Adaptation and the state: Latin America and the challenge of capacity-building under globalization. Global Environmental Change 16:7-18. http:// dx.doi.org/10.1016/j.gloenvcha.2005.10.004

Fenske, R. A. 2002. Incorporating health and ecologic costs into agricultural production. Environmental Health Perspectives 110(5):A228-A229.

Flora, C. B. 2003. Democracy: balancing market, state and civil society. Pages 89-100 in M. M. Bell and F. Hendricks, editors. Research in rural sociology and development. Emerald Group, Bingley, UK. http://dx.doi.org/10.1016/ S1057-1922(03)09006-1

Folke, C., S. R. Carpenter, B. Walker, M. Scheffer, T. Chapin, and J. Rockström. 2010. Resilience thinking: integrating resilience, adaptability and transformability. Ecology and Society 15(4): 20. [online] URL: http://www.ecologyandsociety. org/vol15/iss4/art20/

Folke, C., L. Pritchard, F. Berkes, J. Colding, and U. Svedin. 2007. The problem of fit between ecosystems and institutions: ten years later. Ecology and Society 12(1): 30. [online] URL: http://www.ecologyandsociety.org/vol12/iss1/art30/

Fox, J., and X. Bada. 2008. Migrant organization and hometown impacts in rural Mexico. Journal of Agrarian Change 8(2-3):435-461. http://dx.doi.org/10.1111/ j.1471-0366.2008.00176.x

Fox, J., and J. Gersham. 2000. The World Bank and social capital: lessons from ten rural development projects in the Philippines and Mexico. Policy Sciences 33:399-419. http:// dx.doi.org/10.1023/A:1004897409300

Getz, C., S. Brown, and A. Shreck. 2008. Class politics and agricultural exceptionalism in California's organic agriculture movement. Politics and Society 36(4):478-507. http://dx.doi. org/10.1177/0032329208324709

Gliessman, S. R. 2007. Agroecology: the ecology of sustainable food systems. CRC, Boca Raton, Florida, USA.

Gliessman, S. R., and R. Rosemeyer. 2009. The conversion to sustainable agriculture: principles, processes, and practices. CRC, Boca Raton, Florida, USA. http://dx.doi. org $/ 10.1201 / 9781420003598$

Goldschmidt, W. R. 1946. Small business and the community: a study in central valley of California on effects of scale of farm operations. Report of the Special Committee to Study 
Problems of American Small Business, 79th Congress, 2nd Session, Washington, D.C., USA.

Goodman, D. 2000. Organic and conventional agriculture: materializing discourse and agro-ecological managerialism. Agriculture and Human Values 17(3):215-219.

Goodman, D., and M. Watts. 1997. Globalisingfood: agrarian questions and global restructuring. Routledge, London, UK.

Gottlieb, R., and A. Joshi. 2010. Food Justice. MIT Press, Cambridge, Massachusetts, USA.

Guadarrama-Zugasti, C. 2008. A grower typology approach to assessing the environmental impact of coffee farming in Veracruz, Mexico. Pages 127-154 in C. M. Bacon, V. E. Méndez, S. R. Gliessman, D. Goodman, and J. A. Fox, editors. Confronting the coffee crisis: fair trade, sustainable livelihoods and ecosystems in Mexico and Central America. MIT Press, Cambridge, Massachusetts, USA.

Guiomar, X. 2010. Peri-urban agriculture and local authorities: which policies for which proximities? Example of local policies in Ile de France. Pages 29-44 in M. Galli, S. Lardon, E. Marraccini, and E. Bonari, editors. Agricultural management in peri-urban areas: the experience of an international workshop. Felici Editore, Ghezzano, Italy. [online] URL: http://www.sssup.it/UploadDocs/10701_AMPA stampa.pdf

Guthman, J. 2004. Agrarian dreams: the paradox of organic farming in California. University of California Press, Berkeley, California, USA.

Harrison, J. 2008. Lessons learned from pesticide drift: a call to bring production agriculture, farm labor, and social justice back into agrifood research and activism. Agriculture and Human Values 25(2):163-167. http://dx.doi.org/10.1007/ $\underline{\mathrm{s} 10460-008-9121-5}$

Hazell, P., and S. Wood. 2008. Drivers of change in global agriculture. Philosophical Transactions of the Royal Society B: Biological Sciences 363(1491):495-515. http://dx.doi. org/10.1098/rstb.2007.2166

Holt-Giménez, E., and A. Shattuck. 2011. Food crises, food regimes and food movements: rumblings of reform or tides of transformation? Journal of Peasant Studies 38(1):109-144. http://dx.doi.org/10.1080/03066150.2010.538578

Horrigan, L., R. S. Lawrence, and P. Walker. 2002. How sustainable agriculture can address the environmental and human health harms of industrial agriculture. Environmental Health Perspectives 110(5):445-456.

Howard, P. H. 2009. Organic industry structure. Journal of the New Media Caucus 5(3). [online] URL: http://www. newmediacaucus.org/html/journal/issues.php? $\mathrm{f}=$ papers\&time $=2009$ winter\&page $=$ howard
International Assessment of Agricultural Knowledge, Science and Technology for Development (IAAKSTD). 2009. Global report: agriculture at a crossroads. Island Press, Washington, D.C., USA.

Jaffee, D. 2007. Brewing justice: fair trade coffee, sustainability, and survival. University of California Press, Berkeley, California, USA.

Jha, S., C. M. Bacon, S. M. Philpott, R. A. Rice, V. E. Méndez, and P. Läderach. 2011. A review of ecosystem services, farmer livelihoods, and value chains in shade coffee agroecosystems. Pages 141-208 in B. W. Campbell and S. Lopez Ortiz, editors. Integrating agriculture, conservation and ecotourism: examples from the field. Issues in Agroecology: Present Status and Future Prospectus Series, Volume 1, Springer, Dordrecht, The Netherlands.

Johns, T., and B. R. Sthapit. 2004. Biocultural diversity in the sustainability of developing-country food systems. Food and Nutrition Bulletin 25:143-155.

Kareiva, P., and M. Marvier. 2007. Conservation for the people. Scientific American 297:50-57. http://dx.doi. org/10.1038/scientificamerican1007-50

Kareiva, P., S. Watts, R. McDonald, and T. Boucher. 2007. Domesticated nature: shaping landscapes and ecosystems for human welfare. Science 316(5833):1866-1869. http://dx.doi. org/10.1126/science. 1140170

Kevane, M., and L. C. Gray. 1999. A woman's field is made at night: gendered land rights and norms in Burkina Faso. Feminist Economics 5(3):1-26. http://dx.doi.org/10.1080/13$\underline{5457099337789}$

Kerr, R. B., S. Snapp, M. Chirwa, L. Shumba, and R. Msachi. 2007. Participatory research on legume diversification with Malawian smallholder farmers for improved human nutrition and soil fertility. Experimental Agriculture 43(4):437-453. http://dx.doi.org/10.1017/S0014479707005339

Kloppenburg, J., Jr., S. Lezberg, K. de Master, G. W. Stevenson, and J. Hendrickson. 2000. Tasting food, tasting sustainability: defining the attributes of an alternative food system with competent, ordinary people. Human Organization 59(2):177-186.

Kok, K., and T. (A.) Veldkamp. 2011. Scale and governance: conceptual considerations and practical implications. Ecology and Society 16(2): 23. [online] URL: http://www. ecologyandsociety.org/vol16/iss2/art23

Kremen, C., A. Iles, and C. Bacon. 2012. Diversified farming systems: an agroecological, systems-based alternative to modern industrial agriculture. Ecology and Society 17(4): 44. http://dx.doi.org/10.5751/ES-05103-170444 
Lardon, S., M. Galli, E. Marracinni, and E. Bonari. 2010. Periurbanisation and peri-urban agriculture: issues and proposals. Pages 7-24 in M. Galli, S. Lardon, E. Marraccini, and E. Bonari, editors. Agricultural management in peri-urban areas: the experience of an international workshop. Felici Editore, Ghezzano, Italy. [online] URL: http://www.sssup.it/ UploadDocs/10701_AMPA_stampa.pdf

Lélé, S. M. 1991. Sustainable development: a critical review. World Development 19(6):607-621. http://dx.doi. org/10.1016/0305-750X(91)90197-P

Lin, B. B. 2007. Agroforestry management as an adaptive strategy against potential microclimate extremes in coffee agriculture. Agricultural and Forest Meteorology 144 (1-2):85-94. http://dx.doi.org/10.1016/j.agrformet.2006.12.009

Littig, B., and E. Griessler. 2005. Social sustainability: a catchword between political pragmatism and social theory. International Journal of Sustainable Development 8 (1-2):65-79. http://dx.doi.org/10.1504/IJSD.2005.007375

Lock, K., J. Pomerleau, L. Causer, D. R. Altmann, and M. McKee. 2005. The global burden of disease attributable to low consumption of fruit and vegetables: implications for the global strategy on diet. Bulletin of the World Health Organization 83(2):100-108.

Lyson, T. A, G. W. Stevenson, and R. Welsh. 2008. Food and the mid-level farm: renewing an agriculture of the middle. MIT Press, Cambridge, Massachusetts, USA.

Maffi, L. 2005. Linguistic, cultural, and biological diversity. Annual Review of Anthropology 34:599-617. http://dx.doi. org/10.1146/annurev.anthro.34.081804.120437

Maranges, R. T. 2005. The Baix Llobregat Agricultural Park (Barcelona): agriculture for the future in a high quality periurban area. Fedenatur, Barcelona, Spain. [online] URL: http://www.fedenatur.org/docs/docs/158.pdf

Méndez, V. E., C. M. Bacon, M. Olson, K. S. Morris, and A. Shattuck. 2010. Agrobiodiversity and shade coffee smallholder livelihoods: a review and synthesis of ten years of research in Central America. Professional Geographer 62 (3):357-376. http://dx.doi.org/10.1080/00330124.2010.483638

Minkoff-Zern, L. A., N. Peluso, J. Sowerwine, and C. Getz. 2011. Race and regulation: Asian immigrants in California agriculture. Pages 65-85 in A. H. Alkon and J. Agyeman, editors. Cultivating food justice: race, class and sustainability. MIT Press, Cambridge, Massachusetts, USA.

Millennium Ecosystem Assessment (MEA). 2005. Ecosystems and human well-being: synthesis. Island Press, Washington, D.C., USA.

Mitchell, R. E., and J. R. Parkins. 2011. The challenge of developing social indicators for cumulative effects assessment and land use planning. Ecology and Society 16(2): 29. [online] URL: http://www.ecologyandsociety.org/vol16/iss2/art29/

Moguel, P., and V. M. Toledo. 1999. Biodiversity conservation in traditional coffee systems of Mexico. Conservation Biology 13(1):11-21. http://dx.doi.org/10.1046/ j.1523-1739.1999.97153.x

Mutersbaugh, T. 1998. Women's work, men's work: gender, labor organization, and technology acquisition in a Oaxacan village. Environment and Planning D-Society \& Space 16 (4):439-458. http://dx.doi.org/10.1068/d160439

Mutersbaugh, T. 2004. To serve and to certify: organic coffee, certification services and village cargo service in Mexico. Environment and Planning D: Society and Space Special Issue: New Geographies of Work 22(4):533-552.

Nigh, R. 1997. Organic agriculture and globalization: a Maya associative corporation in Chiapas, Mexico. Human Organization 56(4):427-436.

Norgaard, R. B., and P. Baer. 2005. Collectively seeing complex systems: the nature of the problem. BioScience 55:953-960. http://dx.doi.org/10.1641/0006-3568(2005)055 [0953:CSCSTN]2.0.CO;2

Ostrom, E., 2005. Understanding institutional diversity. Princeton University Press, Princeton, New Jersey, USA. [online] URL: http://press.princeton.edu/chapters/s8085. html

Paige, J. M. 1997. Coffee and power: revolution and the rise of democracy in Central America. Harvard Press, Cambridge, Massachusetts, USA.

Panelli, R., and G. Tipa. 2007. Placing well-being: a Maori case study of cultural and environmental specificity. EcoHealth 4(4):445-460. http://dx.doi.org/10.1007/ s10393-007-0133-1

Perfecto, I., R. A. Rice, R. Greenberg, and M. E. Van der Voort. 1996. Shade coffee: a disappearing refuge for biodiversity. Bioscience 46(8):598-608. http://dx.doi. org/10.2307/1312989

Philpott, S. M., W. J. Arendt, I. Armbrecht, P. Bichier, T. V. Diestch, C. Gordon, R. Greenberg, I. Perfecto, R. ReynosoSantos, L. Soto-Pinto, C. Tejeda-Cruz, G. Williams-Linera, J. Valenzuela, and J. M. Zolotoff. 2008a. Biodiversity loss in Latin American coffee landscapes: review of the evidence on ants, birds, and trees. Conservation Biology 22(5):1093-1105. http://dx.doi.org/10.1111/j.1523-1739.2008.01029.x

Philpott, S. M., B. B. Lin, S. Jha, and S. J. Brines. 2008b. A multi-scale assessment of hurricane impacts on agricultural landscapes based on land use and topographic features. Agriculture, Ecosystems \& Environment 128(1-2):12-20. http://dx.doi.org/10.1016/j.agee.2008.04.016 
Pimentel, D., H. Acquay, M. Biltonen, P. Rice, M. Silva, J. Nelson, V. Lipner, S. Giordano, A. Horowitz, and M. D'Amore. 1992. Environmental and economic costs of pesticide use. BioScience 42(10):750-760. http://dx.doi. org/10.2307/1311994

Pimentel, D., S. Williamson, C. E. Alexander, O. GonzalezPagan, C. Kontak, and S. E. Mulkey. 2008. Reducing energy inputs in the US food system. Human Ecology 36(4):459-471. http://dx.doi.org/10.1007/s10745-008-9184-3

Pretty, J. 2008. Agricultural sustainability: concepts, principles and evidence. Philosophical Transactions of the Royal Society B: Biological Sciences 363(1491):447-465. http://dx.doi.org/10.1098/rstb.2007.2163

Pretty, J. N., C. Brett, D. Gee, R. E. Hine, C. F. Mason, J. I. L. Morison, H. Raven, M. D. Rayment, and G. Van der Bijl. 2000. An assessment of the total external costs of UK agriculture. Agricultural systems 65(2):113-136. http://dx.doi. org/10.1016/S0308-521X(00)00031-7

Pretty, J., and H. Ward. 2001. Social capital and the environment. World development 29:209-227. http://dx.doi. org/10.1016/S0305-750X(00)00098-X

Raynolds, L. T. 2004. The globalization of organic agro-food networks. World Development 32(5):725-743. http://dx.doi. org/10.1016/j.worlddev.2003.11.008

Rice, R. A. 1997. The land use patterns and the history of coffee in eastern Chiapas, Mexico. Agriculture and Human Values 14:127-143.

Rice, R. A., and J. R. Ward. 1996. Coffee, conservation, and commerce in the western hemisphere. Smithsonian Migratory Bird Center/Natural Resources Defense Council, Washington, D.C., USA.

Robson, J. P., and F. Berkes. 2011. Exploring some of the myths of land use change: can rural to urban migration drive declines in biodiversity? Global Environmental Change 21 (3):844-854. http://dx.doi.org/10.1016/j.gloenvcha.2011.04.009

Samper, M. K., and S. Topik, editors. 2012. Crisis y Transformaciones En Le Mundo De Cafe. Universidad Javeriana, Bogotá, Colombia.

Sevilla-Guzmán, E., and J. Martinez-Alier. 2006. New social movements and agroecology. Pages 472-483 in P. Cloke, T. K. Marsden, and P. Mooney, editors. Handbook of rural studies. Sage, London, UK.

Shreck, A., C. Getz, and G. Feenstra. 2006. Social sustainability, farm labor, and organic agriculture: findings from an exploratory analysis. Agriculture and Human Values 23(4):439-449. http://dx.doi.org/10.1007/s10460-006-9016-2

Sneddon, C., R. B. Howarth, and R. B. Norgaard. 2006. Sustainable development in a post-Brundtland world.
Ecological Economics 57:253-268. http://dx.doi.org/10.1016/ j.ecolecon.2005.04.013

Staver, C., F. Guharay, D. Monterroso, and R. G. Muschler. 2001. Designing pest-suppressive multistrata perennial crop systems: shade-grown coffee in Central America. Agroforestry Systems 53(2):151-170. http://dx.doi.org/10.1023/ A:1013372403359

Strochlic, R., C. Wirth, A. F. Besada, and C. Getz. 2009. Farm labor conditions on organic farms in California. California Institute for Rural Studies, Davis, California, USA.

Taylor, P. L. 2005. In the market but not of it: fair trade coffee and forest stewardship council certification as market-based social change. World Development 33(1):129-147. http://dx. doi.org/10.1016/j.worlddev.2004.07.007

Tegtmeier, E. M., and M. D. Duffy. 2004. External costs of agricultural production in the United States. International Journal of Agricultural Sustainability 2(1):1-20. http://dx.doi. org/10.1080/14735903.2004.9684563

Toledo, V. M., and P. Moguel. 2012. Coffee and sustainability: the multiple values of traditional shaded coffee. Journal of Sustainable Agriculture 36(3):353-377. http://dx.doi. org/10.1080/10440046.2011.583719

Toledo, V. M., B. Ortiz-Espejel, L. Cortés, P. Moguel, and M. J. Ordonez. 2003. The multiple use of tropical forests by indigenous peoples in Mexico: a case of adaptive management. Conservation Ecology 7(3): 9. [online] URL: http://www.ecologyandsociety.org/vol7/iss3/art9/

Topik, S. 2009. Historicizing commodity chains: five hundred years of the global coffee commodity chain. Chapter 2 in Jennifer Bair, editor. Frontiers of commodity chain research. Stanford University Press, Stanford, California, USA.

Turner, B. L., R. E. Kasperson, P. A. Matson, J. J. McCarthy, R. W. Corell, L. Christensen, N. Eckley, J. X. Kasperson, A. Luers, M. L. Martello, C. Polsky, A. Pulsipher, and A. Schiller. 2003. A framework for vulnerability analysis in sustainability science. Proceedings of the National Academy of Science of the United States of America 100(14):8074-8079. http://dx. doi.org/10.1073/pnas.1231335100

United Nations Development Programme (UNDP). 2010. Human development report 2010-the real wealth of nations: pathways to human development. 20th Anniversary Edition. UNDP, New York, New York, USA.

Villarejo, D., and S. L. Baron. 1999. The occupational status of hired farm workers. Occupational Medicine 14:613-35.

Walker, R. A. 2004. The conquest of bread. New Press, New York, New York, USA.

Walker, B., C. S. Holling, S. R. Carpenter, and A. Kinzig. 2004. Resilience, adaptability and transformability in social- 
ecological systems. Ecology and Society 9(2): 5. [online] URL: http://www.ecologyandsociety.org/vol9/iss2/art5/

Weber, M., N. Krogman, and T. Antoniuk. 2012. Cumulative effects assessment: linking social, ecological, and governance dimensions. Ecology and Society 17(2): 22. http://dx.doi. org/10.5751/ES-04597-170222

Wells, S. 2011. Pandora's seed: the unforeseen cost of civilization. Random House, New York, New York, USA.

Westphal, S. M. 2008. Coffee agroforestry in the aftermath of modernization: diversified production and livelihood strategies in post-reform Nicaragua. Pages 176-206 in C. M. Bacon, V. E. Méndez, S. R. Gliessman, D. Goodman, and J. A. Fox, editors. Confronting the coffee crisis: fair trade, sustainable livelihoods and ecosystems in Mexico and Central America. MIT Press, Cambridge, Massachusetts, USA.

Wisner, B., J. C. Gaillard, and I. Kelman. 2011. Handbook of hazards and disaster risk reduction. Routledge, London, UK.

Wittman, H. 2009. Reworking the metabolic rift: La Vía Campesina, agrarian citizenship, and food sovereignty. Journal of Peasant Studies 36(4):805-826. http://dx.doi. org/10.1080/03066150903353991

Wittman, H., A. A. Desmarais, and N. Wiebe, editors. 2010. Food sovereignty: reconnecting food, nature and community. Fernwood Publishing, Halifax, Nova Scotia, Canada.

Zimmerer, K., and T. Bassett. 2003. Political ecology: an integrative approach to geography and environmentdevelopment studies. Guilford, New York, New York, USA. 